\title{
English Teachers' Creativity in Conducting Teaching and Learning Process in Public Senior High Schools in Bali
}

\author{
Luh Putu Artini*, Ni Nyoman Padmadewi \\ Postgraduate Study Program \\ Universitas Pendidikan Ganesha \\ Singaraja - Bali, Indonesia \\ *putu.artini@undiksha.ac.id
}

\begin{abstract}
Teachers' creativity plays a major role in determining success in teaching and learning process. This success can be identified through the learning outcome in which students possess the capability to use the foreign language in real life and achieve the 21st century learning skills. Research on teachers' teaching creativity have been conducted world widely, however it is hardly found in the context of Indonesian schools. The purpose of this study was of two folds: first, to examine teachers' perceptions on creativity in teaching, and second, to observe how this perception was reflected in the teaching and learning process. The study involved 12 English teachers from 6 schools, and used self-rated teaching creativity questionnaire, classroom observation sheet, anecdotal records, and in-depth interview. The data were analyzed descriptively based on Miles \& Huberman qualitative data analysis procedures. The findings indicate that there was a notable discrepancy between what was perceived by the teachers and what was observed in the classroom. Teachers perceive themselves as creative, however based on classroom observation data, their efforts fall under the category of lack of creativity. This finding reveals a discrepancy between what teachers' think and do in the classroom which may lead to the need for professional development program in creative teaching.
\end{abstract}

Keywords-teaching creativity, discrepancy, English language teaching

\section{INTRODUCTION}

One of the global competencies that become part of school curricula is competencies in an international language. In most Asian countries, the most popular international language learned at school is English (i.e. English as a Foreign language or henceforth, EFL). In fact, English is not only considered as a school subject but also as a global commodity [1]. In many non-English speaking communities, competence in this international language is closely associated with "economic modernization and industrial development" [2]. For a long time, in Indonesia, competence in EFL is regarded as an asset that affect one's better career and important determinant for success in higher education [3].
Competence in English is especially more important in the 21 st century in which schools' as well as higher education graduates are confronted by global competition in the labor forces. In this globalization era, English is even needed for more purposes, not only for education and career building but also as a medium for technology and media development, entertainment, etc. [2]. For these reasons, there is an increasing role of English teachers in ASEAN countries [4] and obviously affect the number of intake students in English teacher educations.

To cope with 21st century learning, English teachers are obliged to have creativity in conducting an English teaching and learning. This is because they are not only responsible to equip the learners with the language skills but also the learning and innovation skills comprising the 4 Cs (communication, collaboration, critical and creative thinking). These skills help graduates to be adaptable to the rapid changes of science and technology that directly bring tremendous impact in all aspects of life, including schooling. Teachers' success in inserting these skills into the teaching and learning process is very dependent upon their creativity. Teachers' creativity consequently makes their students to be creative [5]. This is confirmed by Henriksen, et al. [6] for whom a teacher should teach creatively to train his / her students to be creative.

Teaching creativity starts from the mindset of a teacher and it is reflected in the teaching strategies in the classroom [5]. There are at least two reasons for an English teacher to be creative. First, a good understanding of the four skills that should be inserted into his/her lesson can be expected to make a teacher think of appropriate teaching strategies that might need to be adapted or created [7]. Second, an ability to plan an effective lesson that meet the expectation of the new curriculum encourages teachers to use their analytical as well as creative thinking. Planning a lesson is an important step for successful teaching. Creativity is even more important during the actual teaching in the classroom. The teacher should assure that the students are fully engaged in meaningful and enjoyable activities. Creativity to plan, implement and evaluate a lesson is 
very important since this directly determines the success of the teaching and learning process [8].

Planning an effective lesson plan requires teachers to be able to foresee what will happen in the classroom when a lesson is planned in such a way. It is not difficult to imagine that there is a close connection between ability to foresee an effective class and an ability to create an effective lesson plan. An innovative teacher will always try new things: new instructional material, new teaching media, new teaching strategies, new tasks, and so on. These are observable during the teaching and learning activities, which lead to an idea that creativity is observable [9]. What teachers do in their classes are the reflection of how they perceive teaching and creativity.

Henriksen and Mishra [10] suggests four things that a teacher may do to be creative. First, to relate the teaching with his/her passion. A teacher who is aware of his/her own passion and make use of this in their teaching will amaze the students and can be expected to improve students' motivation. For example, a teacher may be good at drawing and use this talent to draw on the board for a task. This will attract respect and attention from the students and respectively improve their motivation to do the task. Second, to connect the real problem with the teaching materials. Teachers' ability to connect real problem with the teaching material can motivate students to learn in a way that their engagement to an activity becomes stronger because the real problems make learning more contextual and meaningful. Third, to process creative thoughts. Creative thought can also be reflected from teachers' ability to execute creative thoughts into an activity, which has never been used before by the teacher. Finally, creativity can also be the results of the mistake that a teacher may make previously. All these initiatives made by a teacher explains what is meant by teaching creativity. Thus, teaching creativity is to do with teachers' decision on how to go about teaching which involve a creation of something new or has not been done before that, when implemented in the classroom, will bring a positive impact on students' motivation and enthusiasm in learning. According to Asoodeh, Asoodeh and Zarepour [11], teaching creativity is built through teachers' own life-long experiences, self-evaluation and skills in seeking new information.

Boden mentioned that there are three types of creativity namely [12],[13]: exploratory, transformational and combinational creativity, each of which can be briefly explained as follows:

- Exploratory teaching creativity is to do with effort to explore new ideas from the existing ideas. The decision of the new idea is determined through students' cognitive levels, use of inductive methods, use of technology, and use of various learning activities. Hong, Hou, Zhu, Marinova, [14] add that possessing exploratory creativity means having the ability to pursue new ideas for the benefits of students and their learning.

- Transformational teaching creativity is related to an ability to restructure different dimensions of teaching components or to develop existing ideas for the sake of effective teaching and learning processes.

- Combinational teaching creativity is about efforts to combine various ideas to establish a newly created form of a conceptual space (i.e. structured way that results in new acceptable ideas). Boden further states that the possession of these three types of creativity can be expected to influence the effectiveness of learning [12]

Studies on teachers' teaching creativity in EFL teaching were mostly placed in the context of the 21 st century learning. For example, Henriksen, et al. [6] who attempted to describe the implementation of teachers' creativity in implementing the 21 st century learning, found that teaching creativity was influenced by teachers' education level and the assessment and regulation of the education in implementing the creativity. Rusdin [7] who explored teachers' perception about their readiness to teach the students in the 21 st century learning discovered that there was a significant correlation between the level of education of the teachers and their perceptions about the 21st century learning skills. Al-Qahtani [15] found that EFL teachers in Saudi Arabia had low enthusiasm and were effortless in showing the creativity in the classroom. Roy attempted to investigate whether there were any differences in teachers' perspectives about fostering creativity in their teaching practice [16]. The result showed that teachers understood the notion of teachers' creativity however, in practice, some limitations were found.

As has been indicated by the studies reviewed above, creativity is influenced by many factors, some of them are education level, teaching and learning regulation, readiness in the new trend, and teachers' perceptions or beliefs. So far, In Indonesia, teachers' creativity neither become a topic of professional development nor attention in any supervision. There is also very limited document available (in the context of Balinese schools) pertaining to teachers' creativity. This study is an attempt to describe how Balinese EFL teachers perceive teaching creativity and how they implement that in their classroom. Creativity here refers to Boden three types of creativity [13]: exploratory, transformational, and combinational. Since creativity was investigated in the era of the 21 st century learning, the definition of each type is expanded to the use of technology in teaching [17], and effort to prepare students to have problem solving skills [18]. The research problems comprise:

- What are EFL teachers' perceptions about teaching creativity in the context of 21 st century learning in senior high schools in Bali?

- How do they implement teaching creativity in the classroom?

The purpose of this study is to describe creativity from the perspective of the teachers (perceived creativity) and how they reflect what they know into their teaching and learning activities (observed creativity). 


\section{METHODS}

This study employed an embedded mixed-method design, involving $12 \mathrm{EFL}$ teachers from 6 public senior high schools in Bali, Indonesia. The instruments used in this research include self-rated questionnaire, classroom observation sheet, anecdotal records, and in-depth interview. Each type of creativity was developed into eight statements to make a total of 24 statements that have to be responded by the teachers. During the observation, the same statements were used to classify the creativity of the class activities into unlikely creative (were not observable to use new ideas and technology), slightly creative (were observable occasionally used new ideas and technology), moderately (sometimes use new ideas and technology), creative (often used new ideas and technology), and very creative (always use new ideas and technology). The observations were conducted six times in each school and the data for perception were analyzed using descriptive statistic with the same categorization of the observation data. Interview was finally conducted to support both the perception and observation data.

\section{RESULTS}

The findings of this study are presented in three sub sections: EFL teachers' perceived creativity, observed creativity, and the discrepancy between the perceived and observed creativity. Perceived creativity in this research refers to teachers' creativity from the perspective of the teacher that is reflected from their responses toward 24 creativity questionnaire items. The observed creativity is from which data on observation were based on. Teachers were observed during the teaching and learning process and every activity were noted and classified. Before presenting the overall data, it is important to see the statements for each type of creativity, as shown in Table 1.

TABLE I.

STATEMENTS FOR EACH TYPE OF CREATIVITY

\begin{tabular}{|l|l|l|l|}
\hline No & \multicolumn{3}{|c|}{ Types of Creativity } \\
\cline { 2 - 5 } & $\begin{array}{l}\text { Exploratory } \\
\text { Transformational } \\
\text { various activities in } \\
\text { classroom }\end{array}$ & $\begin{array}{l}\text { I am able to create } \\
\text { challenging material } \\
\text { by using problem in } \\
\text { learning process }\end{array}$ & $\begin{array}{l}\text { I am able to } \\
\text { modify old } \\
\text { learning media to } \\
\text { become the } \\
\text { unique one. }\end{array}$ \\
\hline 2 & $\begin{array}{l}\text { I am able to engage } \\
\text { students in learning } \\
\text { process }\end{array}$ & $\begin{array}{l}\text { I am able to teach } \\
\text { based on the real } \\
\text { problem of the } \\
\text { students }\end{array}$ & $\begin{array}{l}\text { I am able to apply } \\
\text { combination of } \\
\text { printed media and } \\
\text { newly electronic } \\
\text { media in learning } \\
\text { process. }\end{array}$ \\
\hline 3 & $\begin{array}{l}\text { I am able to teach } \\
\text { based on the lesson } \\
\text { plan and learning } \\
\text { objectives }\end{array}$ & $\begin{array}{l}\text { I am able to make } \\
\text { classroom more active } \\
\text { and innovative }\end{array}$ & $\begin{array}{l}\text { I am able to } \\
\text { deliver learning } \\
\text { materials by using } \\
\text { various } \\
\text { technology-based } \\
\text { learning media. }\end{array}$ \\
\hline 4 & $\begin{array}{l}\text { I am able to create } \\
\text { group } \\
\text { individual activities } \\
\text { in the classroom }\end{array}$ & $\begin{array}{l}\text { I am able to make } \\
\text { students solve the } \\
\text { problem by using their } \\
\text { own prior knowledge }\end{array}$ & $\begin{array}{l}\text { I am able to } \\
\text { modify } \\
\text { function } \\
\text { existed learning }\end{array}$ \\
\hline
\end{tabular}

\begin{tabular}{|c|c|c|c|}
\hline & & & $\begin{array}{l}\text { media in the } \\
\text { classroom. }\end{array}$ \\
\hline 5 & $\begin{array}{l}\text { I am able to build } \\
\text { students' cognitive } \\
\text { through inductive } \\
\text { learning process }\end{array}$ & $\begin{array}{l}\text { I am able to create } \\
\text { different media in } \\
\text { each meeting }\end{array}$ & $\begin{array}{l}\text { I am able to } \\
\text { integrate concrete } \\
\text { life as supporting } \\
\text { ideas for the } \\
\text { materials given. }\end{array}$ \\
\hline 6 & $\begin{array}{l}\text { I am able to teach } \\
\text { using various } \\
\text { teaching technique } \\
\text { steps order and rules }\end{array}$ & $\begin{array}{l}\text { I am able to use } \\
\text { conventional media } \\
\text { when necessary }\end{array}$ & $\begin{array}{lr}\text { I am able } & \text { to } \\
\text { combine } & \text { any } \\
\text { attractive } & \\
\text { activities } & \text { to } \\
\text { deliver } & \text { the } \\
\text { material. } & \end{array}$ \\
\hline 7 & $\begin{array}{l}\text { I am able to use } \\
\text { technology to } \\
\text { facilitate teaching } \\
\text { and learning process }\end{array}$ & $\begin{array}{l}\text { I am able to make } \\
\text { students think } \\
\text { creatively about the } \\
\text { problem solving }\end{array}$ & $\begin{array}{l}\text { I am able to } \\
\text { combine some } \\
\text { audio or visual } \\
\text { medias in learning } \\
\text { activities. }\end{array}$ \\
\hline 8 & $\begin{array}{l}\text { I am able to create } \\
\text { innovation in } \\
\text { teaching by using } \\
\text { technological media }\end{array}$ & $\begin{array}{l}\text { I am able to give } \\
\text { students real problem }\end{array}$ & $\begin{array}{l}\text { I am able to use } \\
\text { any online or } \\
\text { offline platform to } \\
\text { support the } \\
\text { learning process. }\end{array}$ \\
\hline
\end{tabular}

Table 1 shows the indicators for each type of creativity and they become the major instrument for collecting both the perception and the observation data. This table is also the reference for data interpretation throughout the findings and discussion section.

\section{A. Teachers' Perceived Creativity}

From the perspective of the teachers, they think that they are creative teachers as demonstrated by Table 2 .

TABLE II. BALINESE EFL TEACHERS’ PERCEIVED CREATIVITY IN TEACHING

\begin{tabular}{|l|l|l|l|}
\hline No. & \multicolumn{1}{|c|}{$\begin{array}{c}\text { Types of } \\
\text { Creativity }\end{array}$} & $\begin{array}{c}\text { Score on Teachers' } \\
\text { Perception }\end{array}$ & Criteria \\
\hline 1 & Exploratory & 3.80 & Creative \\
\hline 2 & Transformational & 3.82 & Creative \\
\hline 3 & Combinational & 3.91 & Creative \\
\hline Average & 3.84 & Creative \\
\hline
\end{tabular}

These data reveal that English teachers rated themselves above moderate level of creativity. The considered themselves as having the high standard of activities either in the pre activities, whilst activities and post activities. They, for example, believed that they created innovation in teaching by using technological media, they made students solve the problem by using their own prior knowledge, as well as they were capable of combining any attractive activities to deliver the materials. These exemplify the three types of creativity that consistently fall into the category of 'creative'. However, when it comes to the data from observation, the findings were strikingly different.

\section{B. Teachers' Observed Creativity}

As mentioned earlier, observations were conducted 6 times in each school utilizing observation sheet and anecdotal records. The data from observation are presented in Table 3. 
TABLE III. BALINESE EFL TEACHERS’ OBSERVED CREATIVITY IN TEACHING

\begin{tabular}{|c|l|l|l|}
\hline No & \multicolumn{1}{|c|}{$\begin{array}{c}\text { Types of } \\
\text { Creativity }\end{array}$} & $\begin{array}{c}\text { Score on } \\
\text { Observation on } \\
\text { Teachers' Creativity }\end{array}$ & Criteria \\
\hline 1 & Exploratory & 2.04 & Slightly Creative \\
\hline 2 & Transformational & 1.86 & Slightly Creative \\
\hline 3 & Combinational & 1.66 & Slightly Creative \\
\hline \multicolumn{2}{|l|}{ Average } & 1.85 & Slightly Creative \\
\hline
\end{tabular}

The observation data reveal that teachers were struggling to show their teaching creativity as seen from the average score of 1.85 which belong to the category of slightly creative. Almost no indication of creativity observed during the teaching and learning activities. For example, in the exploratory creativity of the use of technology (i.e. I am able to use technology to facilitate teaching and learning process) teachers perceived themselves as creative class instructors. The self-rated responses indicated the scores of 3,4, and 5, which the dominance of 4 . In the transformational creativity, the perceived creativity scores were higher that the corresponding creativity in the classrooms. However, based on the observation data, all the observed teachers hardly used technology-based instruction or media to support the learning activities. Some classrooms had an LCD projector, but during the six times of observation, only 3 teachers used the device once. Similarly, in the transformational creativity regarding problem solving skills (i.e. I am able to make students think creatively about the problem solving) teachers thought that they provided an opportunity for the students to use their creative thinking through problem solving activity). However, during the observation, students we assigned to do controlled activities in which the teacher checked if students' work on a task was right or wrong. In term of combinational creativity, teachers rated their creativity as high. The observation data reveals a contradictory result in which the average score also fell under low creativity. In the item to do with technology (I am able to deliver learning materials by using various technology-based learning media), the self-rate scores made by the teacher was in the category of creative. The observation, however, revealed that the teacher hardly used any technologybased teaching media.

The significant gaps between the perceived and the observed creativity were then explored through interviews with the teachers. When a question of why they did not use technology-based teaching media, one of the interesting responses was that the topics did not require them to use a lcd projectors or any other devises. The following excerpt illustrates the teachers' reasons for employing conventional teaching strategy instead of employing creative EFL teaching.

\section{Interviews}

Below are the excerpts from the interview with the teachers.

\section{1) Interview excerpt \#1}

“... Kita jelaskan dulu. Kalau misal kayak waktu ini saya tidak pakai PowerPoint dijelaskan aja langsung. Jelaskan dulu. setelah itu tanya any question? Pertama sih saya pancing dulu. What are you doing now? Swimming, speaking dan sebagainya. Nah yang -ing, -ing itu apa, misalnya itu kan lebih identik gerund sama present continuous. Setelah itu baru kita jelaskan rumusnya baru mereka buat contoh kalimatnya, saya kasi soal, langsung saya nilai langsung dah selesai waktu itu, satu hari selesai..." [T1/7-4]

“...We explain first. Like in the meetings (that you observed) I did not use PowerPoint, I just explained verbally. I explained first then I asked any question?" First of all, I elicit from them, "what are you doing now? Swimming, speaking and so on". What is -ing, -ing for. For example, it was more identical with gerund and present continuous. After that, I will explain the formula [sentence structure], then they will make the sentences, I will give the task, and I immediately score their work. One material will be finished in one meeting..."

This interview shows teachers' actual practice of teaching in the classroom in which the components of the 21st century learning was hardly seen. Classes were mostly teacher-centered in nature in which deductive approach was used much because the emphasis of teaching was on grammar. From class to class, it is common that the teacher starts with an explanation and followed with exercises. In fact, there were repetitive responses that inductive approach was not used in the classroom for some reasons as revealed in the following interview excerpt.

\section{2) Interview excerpt \#2}

“...Saya terkadang lebih menyukai sistem mengajar yang conventional kayak mengajar jaman dulu. Because they miss that. Terkadang ya misalnya waktu saya mengajar passive voice ya terus materi yang dibuku kurang memuaskan trus siswanya di sruh baca di buku pasti siswanya bingung "apaan nih gak ngerti" dan siswanya itu malas membaca jadi sometimes they miss guru itu explain..." [T4/6-4]

“...I sometimes prefer conventional teaching systems like teaching in the past. Because they [the students] miss that. Sometimes when I, for example, teach passive voice, and the material in the book is not satisfying, then the students are reading in books, the students are confused, "What do you not understand" and the students are lazy to read, so sometimes they miss the teacher explain..."

From the teacher's perspective, students prefer to listen to his/her explanation. Students were happier when their teacher talk, and they listen and appreciate their teacher for telling them what to do instead of learning on their own based on the existing student book. Teacher's preference to apply traditional teaching in this excerpt was supported by the following excerpt.

3) Interview excerpt \#3

"...Siswa kita disini agak susah kalau diajarkan secara inductive, kadang di tanya malah bengong. Coba kalian bayangkan dulu waktu SMA lebih enak mana di jelasin langsung oleh guru atau belajar rumus sendiri. Ini kyak sudah 
jadi budaya buat siswa di Indonesia khusunya di desa. Kalau murid di kelas ini di tekan belajar dengan pola seperti itu, I think you know what it would be..." [T3/5-4]

"...Our students here are rather difficult if they are taught inductively, sometimes they are confused if get question. You can imagine when you were in high school, [tell me now] which one is better, to be told directly by the teacher or to learn on your own [?]. This has become a culture for students in Indonesia especially in the village. If students in this class are pushed to learn in such a pattern, I think you know what it would be [like]..."

From three quotations from the interview data, it is not difficult to imagine how much creativity was put into an EFL class in senior high schools in Bali, Indonesia. One of the components of the 21century learning is creativity which should be modelled by the teacher [19]. It is not only through exploratory, transformational, or combinational model [13], but also through the utilization of technology [20]. Further, these scholars point out that creativity should already appear since the beginning of a lesson, so that students' motivation and enthusiasm can be maintained throughout the lesson. In this way students will experience an attractive teaching and learning process [21] that will lead to a successful education [22]. When a teacher is creative, she/he will be consistently creative and always comes up with fresh ideas in teaching.

\section{CONCLUSION}

The findings of this study that there is a wide gap between the perceived and observed creativity of EYL teachers in Senior High schools in Bali indicate that teachers tend to have adequate knowledge about teaching creativity and understand how it should be implemented in the classroom. However, in real teaching this knowledge is not much used probably because there is no clear standard for creativity in the classroom. This is in line with Al-Qahtani [15] who found that EFL teachers in Saudi Arabia were lack of enthusiasm and effort in showing creativity in the classroom even though they have adequate background knowledge about what is meant by teaching creativity. Further study needs to be conducted to explore whether there are common pedagogical reasons to limit teaching creativity across the variable of cultures and education systems.

\section{REFERENCES}

[1] C.M.E. Whitehead, "Planning Policies and Affordable Housing: England as a Successful Case Study?," Hous. Stud., vol. 22, no. 1, pp. 25-44, 2007.

[2] M.A. Hasman, "The Role of English in the 21st Century," Tesol Chile, vol. 1, no. 1, pp. 18-21, 2004.
[3] L.P. Artini, "Learning English in Bali: Investigating Beliefs and Language Learning Strategies," Unpubl. PhD thesis, 2006.

[4] A. Kirkpatrick, "English as an International Language in Asia: Implications for Language Education," in English as an international language in Asia: Implications for language education, Springer, 2012, pp. 29-44.

[5] T. Cremin, "Creative Teachers and Creative Teaching," Creat. Prim. Educ., vol. 11, no. 1, pp. 36-46, 2009.

[6] D. Henriksen, M. Henderson, E. Creely, S. Ceretkova, M. Černochová, E. Sendova, E.T. Sointu, and C.H. Tienken, "Creativity and Technology in Education: An International Perspective," Technol. Knowl. Learn., vol. 23, no. 3, pp. 409-424, 2018.

[7] N.M. Rusdin, "Teachers' Readiness in Implementing 21st Century Learning," Int. J. Acad. Res. Bus. Soc. Sci., vol. 8, no. 4, pp. 12931306, 2018.

[8] W. Morris, "Creativity-Its Place in Education," New Zeal., 2006

[9] Z. Ivcevic, "Creativity Map: Toward the next Generation of Theories of Creativity.," Psychol. Aesthetics, Creat. Arts, vol. 3, no. 1, p. 17, 2009.

[10] D. Henriksen and P. Mishra, "Learning from Creative Teachers," Educ. Leadersh., vol. 70, no. 5, pp. 123-146, 2013.

[11] M.H. Asoodeh, M.B. Asoodeh, and M. Zarepour, "The Impact of Student-Centered Learning on Academic Achievement and Social Skills," Procedia-Social Behav. Sci., vol. 46, pp. 560-564, 2012.

[12] M.A. Boden, "Creativity in a Nutshell," Think, vol. 5, no. 15, pp. 83-96, 2007.

[13] M.A. Boden, "Creativity and Artificial Intelligence," Artif. Intell., vol. 103, no. $1-2$, pp. 347-356, 1998.

[14] J. Hong, B. Hou, K. Zhu, and D. Marinova, "Exploratory Innovation, Exploitative Innovation and Employee Creativity," Chinese Manag. Stud., 2018

[15] A.A. Al-Qahtani, "Why Do Saudi EFL Readers Exhibit Poor Reading Abilities," English Lang. Lit. Stud., vol. 6, no. 1, pp. 1-15, 2016.

[16] J. Roy, "Elementary Teacher Perceptions of Teaching Practices That Foster Creative Thinking in Students," Inq. Univ. Arkansas Undergrad. Res. J., vol. 14, no. 1, p. 9, 2013

[17] E. Van Laar, A.J.A.M. Van Deursen, J.A.G.M. Van Dijk, and J. De Haan, "The Relation between 21st-Century Skills and Digital Skills: A Systematic Literature Review," Comput. Human Behav., vol. 72, pp. 577-588, 2017

[18] A. Ball, H.D. Joyce, and D. Anderson-Butcher, "Exploring 21st Century Skills and Learning Environments for Middle School Youth,” Int. J. Sch. Soc. Work, vol. 1, no. 1, p. 1, 2016

[19] A.H. Wahid, C. Muali, and M. Mutmainnah, "Manajemen Kelas Dalam Menciptakan Suasana Belajar Yang Kondusif; Upaya Peningkatan Prestasi Belajar Siswa," al-fikrah J. Manaj. Pendidik., vol. 5, no. 2, pp. 179-194, 2018

[20] P. Setiono and I. Rami, "Kreativitas Guru Dalam Menggunakan Media Pembelajaran Di Kelas V Sekolah Dasar," J. Gentala Pendidik. Dasar, vol. 2, no. 2, pp. 219-236, 2017.

[21] M. Barak, "Teaching Methods for Systematic Inventive Problem-solving: Evaluation of a Course for Teachers," Res. Sci. Technol. Educ., vol. 24, no. 2, pp. 237-254, 2006.

[22] E. Hammar Chiriac, "Group Work as an Incentive for LearningStudents' Experiences of Group Work," Front. Psychol., vol. 5, p. 558, 2014. 